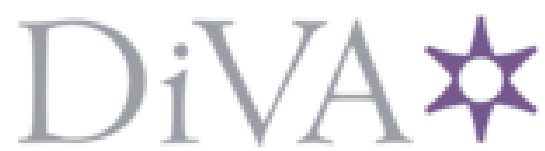

http://www.diva-portal.org

\title{
Postprint
}

This is the accepted version of a paper published in Edinburgh Law Review. This paper has been peerreviewed but does not include the final publisher proof-corrections or journal pagination.

Citation for the original published paper (version of record):

Reyes Molina, S. (2016)

Michael Giudice, Understanding The Nature of Law: A Case for Constructive Conceptual

Explanation.

Edinburgh Law Review, 20(3): 415-416

http://dx.doi.org/10.3366/elr.2016.0381

Access to the published version may require subscription.

N.B. When citing this work, cite the original published paper.

Permanent link to this version:

http://urn.kb.se/resolve?urn=urn:nbn:se:uu:diva-307704 


\section{Michael Giudice, UNDERSTANDING THE NATURE OF LAW: A CASE FOR CONSTRUCTIVE CONCEPTUAL EXPLANATION}

Cheltenham: Edward Elgar Publishing, 2015. ix +253 pp.

ISBN $978178471880 . £ 80$.

During the past century, Common Law scholars have often commended analytical jurisprudence as the best method available for the study of law. Yet, analytical jurisprudence fell from grace at the close of the $20^{\text {th }}$ century as it was overshadowed by new approaches based on the works of philosophers such as Quine and Kripke, among others. Conceptual analysis, trademark of analytical jurisprudence, came under severe criticism as insufficient or useless to explain its own object of inquiry.

This is the context of Michael Giudice's Understanding the Nature of Law: A Case for Constructive Conceptual Explanation. Through ten chapters, divided in three sections, Giudice defends analytical jurisprudence. His aim is to "save the heart of the goal of analytical jurisprudence and preserve some of its methods, while reframing the goal and reforming those methods to account for criticisms whose merits cannot be rejected"(4). His claim is straightforward: analytical jurisprudence is not dead and it still constitutes a formidable methodology to explain and understand law. Yet, in order to ensure that analytical jurisprudence abides by its promise, Giudice argues that it must reconsider its object of study and approach it differently. It cannot develop solely from the identification of the necessary features and relations of law, a task for conceptual explanation; it needs also take into account those contingent features and specific relations that are critical for a deeper understanding of the different experiences of law. This task, in his view, constitutes the method of constructive conceptual explanation, which aims to "the construction of new and improved concepts for use in explaining social reality" (38). Giudice turns to constructivism as the philosophical method that will inform his claims. Through constructive conceptual explanation Giudice seeks to introduce a method to revise and expand long-standing concepts in ways responsive to new challenges.

The strategy is innovative, as Giudice does not try to discredit or confront the critics of analytic jurisprudence. Rather, he acknowledges their merits and uses them to further his own argumentative trajectory. Critiques are bright spots that mark the way along which analytical jurisprudence should pursue in order to achieve its goals. Following Giudice's main thesis, conceptual explanation is not the goal of analytic philosophy but only the beginning. The main task lies rather in the philosophical construction of new and improved concepts to be employed in explaining and understanding law and its place in social reality. According to Giudice, both conceptual explanation and constructive conceptual explanation are two sides of the method of conceptual analysis. Both are types of morally-neutral descriptive explanations of law that lay out a relevant framework and constitute important analytical tools for thinking about law whenever and wherever it exists.

Giudice succeeds in revisiting constructivism in order to draw from it a new method that he calls constructive conceptual explanation. He portrays it as one of the most important tools of conceptual analysis in jurisprudence given that it allows for the identification of contingent features and relations of law. Granted that its aim is to improve our understanding of law, Giudice refers to law in a general fashion and not to any given legal system. Yet, most of the sources analysed do not seem to support his theoretical generalizations. Whilst Giudice seems genuinely concerned with legal systems outside the Common Law as a way of making his theoretical claims generalizable, he still grounds his entire theoretical argument on Common Law 
theorists. This significantly weakens the author's ability to make strong claims about law that speak to all legal traditions. The risk here is that the discussion becomes selfreferential between scholars who share the same legal background. Just as analytic jurisprudence is more than conceptual explanation, a general account of law must also move beyond the mere perspective of a particular legal tradition.

The first section contains the first four chapters of the book. Here Giudice presents an overview of the method of conceptual analysis both in analytic philosophy and legal theory. Giudice's clear prose allows for a structured and systematic account of the main features of this method. He critically presents three contemporary challenges to conceptual analysis: the delimitation challenge, the naturalized jurisprudence challenge and the pluralist challenge. Even though, Giudice acknowledges the merit of these challenges, he claims that the key error in each of them is to identify conceptual analysis with conceptual explanation: this is an incomplete reconstruction of what conceptual analysis entails because it ignores the role of constructive conceptual explanation in the analysis of law.

Giudice claims that analytic jurisprudence must shift its focus from conceptual analysis to constructive conceptual explanation. For this, he relies heavily on the theory presented by H.L.A. Hart in The Concept of Law. According to Giudice, Hart's theory is an example of how a set of philosophical claims about law that begun as conceptual analysis moved towards constructive conceptual explanation where both conceptual and contingent features and relations of law might be identified.

Section two contains chapters five and six of the book. Giudice goes on in the second section to test his claims, by analysing two substantive debates in legal theory from the viewpoint of constructive conceptual explanation: a) the relation between moral principles and legal validity - by addressing the relation of unconstitutionality and invalidity from the perspective of exclusive positivism - and b) the nature of EU law - by addressing the issue of the ultimate source of validity of EU law.

Section three contains the last four chapters of the book. Here Giudice develops an account of continuity between different disciplinary approaches to law such as conceptual, moral, social sciences and political approaches. The author claims that current methodologies in legal theory are insufficient to explain how the different approaches are interconnected and therefore fail to give us a complete picture of this social phenomenon. The central claim of this section is that constructive conceptual explanation is coterminous with all these approaches and, by identifying and explaining the contingent relations of law, it "yields a truly superior way of understanding the goals of legal theory" (214).

Sebastián Reyes Molina Uppsala University 